\title{
Seeds Potentialities of Medicks in Sub-Humid Area to be used in Steppe Zone
}

\author{
Alane $\mathrm{F}^{2}$, R.Chabaca ${ }^{1}$, Abdelguerfi-Laouar. $\mathrm{M}^{3}$, Abdelguerfi $\mathrm{A}^{1}$ \\ ${ }^{1,3}$ National Superior School of Agronomy El Harrach, Algeria \\ ${ }^{2}$ National Agronomy Research Institute of Nari Baraki, Algeria
}

\begin{abstract}
New pulse crops varieties more productive as medics should be made available to breeders located in semi-arid region of Algeria. So, and through two years of testing, pods yield and seeds production of twenty populations belonging to species M.intertexta, M.ciliaris, M.polymorpha, M.Truncatula and an introduced population M.muricoleptis is an Australian cultivar (Jemalong) are appreciated.Pods' yields of year 2013 vary between $78,66 \mathrm{~g} / \mathrm{m}^{2}$ with poly 27 and $3637,33 \mathrm{~g} / \mathrm{m}^{2}$ with $I_{107}$. Values of the second essay (2015) are different, they vary between $40,89 \mathrm{~g} / \mathrm{m}^{2}$ with Poly 236 and $464,36 \mathrm{~g} / \mathrm{m}^{2}$ with I11.The cultivar Jemalong offers a yield of $172,4 \mathrm{~g} / \mathrm{m}^{2}$. The corresponding seed yields also show a low production in year 2015. The ratio leaf / stem varies between 1,03 and 5. The average of yields in dry matter of 27 populations in 2013 was of $457,79 \mathrm{~g} / \mathrm{m}^{2}$ against $127,41 \mathrm{~g} / \mathrm{m}^{2}$ in 18 populations in 2015. Jemalong cultivar records a yield of $12,8 \mathrm{~g} / \mathrm{m}^{2}$. For the same dose of seed, number of plants by square meter varies between 44 and 112. Number of stems by square meter varies between 136 in $C_{204}$ and 420 in $I_{52 . .}$ The average width of population's ramifications varies between $13 \mathrm{~cm}$ in $\operatorname{Tr}_{334}$ and $44 \mathrm{~cm}$ in $I_{52}$, The Jemalong cultivar offers an average of $17 \mathrm{~cm}$. So, production results of medicks depend of weather conditions in littoral zone of lower altitude than 600-700m. In steppe zones, we recommend to make tests in situ with these same populations.
\end{abstract}

Keywords-Medicago, medicKs, populations, pods, yield in seed.

\section{INTRODUCTION}

Husbandry of ruminants is mainly located in arid regions of Algeria, in about 1/5 of the total area. This important availability of agricultural land requires fodder production In fact, fodder grown is one of the solutions considered, pass through intensification of fodder production, per unit of area, not only in quantitative terms ( $\mathrm{kg}$ of fodder produced by $\mathrm{m}^{2}$ ) but also in qualitative terms with a net improvement of nutritional quality. New pulse crops varieties more productive and with better nutritional value should be available to the breeders. Much appreciated by livestock, as well in green as in dry, pulse crops are richer in nutrients mainly in digestible nitrogenous matter, in vitamins and in mineral $(2,5 \mathrm{~kg}$ of alfalfa hay represents 1 UF) (Bouaboub -Mousab., 2012). M. truncatula is a potential grazing cultivation that products high fodder level of good quality. A study carried out in South-East of Wyoming during 3 years, on three cultivars of $\boldsymbol{M}$ truncatula which are Calife, Mogul et Paraggio, revealed that average yield in dry matter was respectively of 1.6, 3.1 et $4.0 \mathrm{t} / \mathrm{ha}$ (Babita., 2008).

The first researchers' objectives have been to study kinds of Medicago, Trifolium, Scorpiurus, Hedysarum and Onobrychis (Abdelguerfi., 2000), They showed a positive correlation between bio geographical parameters, particularly altitutde and rainfall, and biological aspects linked to the growth and reproduction - flowering inflorescences, pods and seeds. The 2/3 of Medicago's genus species (they are gathered under the term of medicKs). Originating of Mediterranean zone, are particularly adapted to drought conditions: Australia, Chile, California...Piano et Talamucci, 1996). Thanks to accumulation of dry grains, MedicKs' meadow regenerates between two cereal crops even after several years. This system is applied in various dry cereal areas: Maghreb, Middle East, Spain... (SAREP. 2013).

Diversification of steppe pastures by a combination of medicKs 'species allows increasing a chance to succeed in their plantation. If one of the cultures dies due to the drought or to the pests, another culture can allow saving the pasture. This allows to put in place pastures more sustainable and increasing soil security. In a well drained soil, sprigs of medicKs can contribute to increase soil organic matter. So, by improving soil health, pulses also help to biodiversity of micro-organisms present into the soil. They can biologically fix more than $350 \mathrm{~kg}$ of nitrogen by hectare and by year (FAO., 2015).

The production of pulses is a water-saving, notably if we compare it to other protein sources, such as for instance: Indian dal (split peas, lentils) which necessitates 50 water liters by kg. Conversely, it is needed 4.325 water's liters to product $1 \mathrm{~kg}$ of poultry, 5.520 water's liters to product $1 \mathrm{~kg}$ of mutton and 13.000 water liters to product $1 \mathrm{~kg}$ of beef. The low water footprint of pulses is an intelligent cultivation choice in areas and in arid regions, subject to drought (FAO. 2015). Thanks to their hard grains and 
drought tolerant, roots can enter 5 feet $(1.524 \mathrm{~m})$ in depth to maintain soil in place and value drops of water (SAREP, 2013). Much constraint prevents annual alfalfa extension, local or introduced in Algeria.

However, we have been interested through two testing years in pods yield and to seeds production of about 20 populations belonging to species of M.intertexta M.ciliaris, M.polymorpha, M.Truncatula and a population introduced belonging to M.muricoleptis and so an Australian cultivar (Jemalong). At the same time, we have tried to approach determining parameters of this production which is: (i) green and dry matter (ii) width of ramifications (iii) weight of 50 pods and their seed (iiii) and number of stems by square meter. These data are thus, very interesting because during dry period, from June to October, pods constitute an available food for animals.

\section{MATERIAL AND METHODS}

The first trial is set on 13/12/2012 and the second on 24/12/2014 at the experimental farm of National Superior School of Agronomy, located in Algiers City.This station is at $30^{\circ} 8^{\prime}$ of longitude and latitude of $36^{\circ} 43^{\prime}$ north and altitude of $48 \mathrm{~m}$. The previous cultural element of the first essay was corn, and for the second one was a fallow. The essay is a full random block with three repetitions. In each block, we have 20 populations for the first essay and 22 populations for the second one, represented each one by four lines of 1 meter with interval of $60 \mathrm{~cm}$ with 80 grains by population and by line. Every block is spaced from other of $1.50 \mathrm{~m}$ for the first essay and of $60 \mathrm{~cm}$ for the second one.

The chemical-physics analysis of the soil was carried out on samples harvested on the plot before seeding, at depths of $20 \mathrm{~cm}$ and $40 \mathrm{~cm}$. At the first essay the texture is silty (soils texture triangle), the soil is rich in calcium and low in nitrogen and organic matters, potassium and sodium. As for the second essay, texture is silty-clayey, low in nitrogen and in organic matter, a $\mathrm{pH}>7,23$ (analysis carried out in Department of Soil Science of ENSA in 2013 and 2015.

Climatic conditions of the experiment period of the first essay 2013 gave a monthly temperature, the highest in May, with an average of $17.8^{\circ} \mathrm{c}$ with maximal of $23^{\circ} \mathrm{c}$. The coldest month was February with an average of $11.5^{\circ} \mathrm{c}$. The coldest day recorded $5.9^{\circ} \mathrm{c}$. The highest rainfall amount recorded was of $137 \mathrm{~cm}$ in three days. As for year 2015, the most rainy month was January with $98,9 \mathrm{~mm}$ and the hottest month was August with an average of $38.4^{\circ} \mathrm{c}$. The maximum and minimum of temperature was also recorded in August with $39^{\circ} \mathrm{c}$ and $1.2^{\circ} \mathrm{C}$ (The agro-meteorology of ENSA, 2013 and 2015).The plant material used which comes from collection of the school is shown in table 1 .

Table.1: Code and origins of the populations studied and the average weight of 1000 seeds

\begin{tabular}{|c|c|c|c|}
\hline Species & Populations' code & $\begin{array}{c}\text { Weight of 1000 } \\
\text { grains }\end{array}$ & Origins \\
\hline $\begin{array}{c}\text { M.truncatula } \\
\text { M.intertexta }\end{array}$ & $\mathrm{Tr}_{201} \mathrm{Tr}_{407} \mathrm{Tr}_{238} \quad \mathrm{Tr}_{334}$ & $3,58 \mathrm{~g}$ & Algeria (2004) \\
$\begin{array}{c}\text { M.ciliaris } \\
\mathrm{I}_{756} \mathrm{I}_{107} \mathrm{I}_{407} \mathrm{I}_{11} \mathrm{I}_{31} \mathrm{I}_{52}\end{array}$ & $15,77 \mathrm{~g}$ & Algeria (2004) \\
$\begin{array}{c}\text { M.polymorpha } \\
\mathrm{S}_{3} \mathrm{C}_{2} \mathrm{C}_{204} \mathrm{~S}_{5} \mathrm{~S} 15 \mathrm{~S} 7 \mathrm{C} 11 \mathrm{C} 58\end{array}$ & $13,21 \mathrm{~g}$ & Algeria (2004) \\
$\begin{array}{c}\text { M.muricoleptis } \\
\text { poly } 27 \text { Poly } 205\end{array}$ & $3,24 \mathrm{~g}$ & Algeria (2004) \\
$\begin{array}{c}\text { M.truncatula CV } \\
\text { Jemalong }\end{array}$ & Aus & $6,26 \mathrm{~g}$ & Turkey (2004) \\
\hline
\end{tabular}

Softwares used for statistical analysis are: Stat View and Statistica.

\section{RESULTS AND DISCUSSION}

Yields in dry matter of population vary between $1132,1 \mathrm{~g} / \mathrm{m}^{2}$ in $\mathrm{I}_{52}$ and $38,85 \mathrm{~g} / \mathrm{m}^{2}$ in $\operatorname{Tr}_{221}$ en 2013 while in 2015 they vary between $453,33 \mathrm{~g} / \mathrm{m}^{2}$ in $\mathrm{I}_{31}$ and $12,56 \mathrm{~g} / \mathrm{m}^{2}$ in $\mathrm{S}_{15}$. The average of 20 populations in 2013 is of $457,79 \mathrm{~g} / \mathrm{m}^{2}$ against $127,41 \mathrm{~g} / \mathrm{m}^{2}$ in 18 populations in2015. Jemalong cultivar records a yield of $12,8 \mathrm{~g} / \mathrm{m}^{2}$. In region of Tunisia yields in gram by square meter of dry matter (DM) of M.polymorpha vary from 84 to 530, M.truncatula varies from 31 to 450 while Jemalong CV witness varies from 0 to 340 . The average of six species of annual alfalfa varies from $102 \mathrm{~g} / \mathrm{m}^{2}$ to $483 \mathrm{~g} / \mathrm{m}^{2}$ (Seklani et Hassen., 1990 in Seklani et al., 1996.). 
En Alaska, yields of 339 to $384 \mathrm{~g} / \mathrm{m}^{2}$ of DM have been obtained in average on two doses of fertilizer $\mathrm{N}, 0$ and 90 $\mathrm{kg} / \mathrm{ha}$, on a neutral ground (Panciera et Sparrow., 1995). The average of ramifications width of populations varies between $13 \mathrm{~cm}$ in $\operatorname{Tr} 334$ and $44 \mathrm{~cm}$ in $\mathrm{I}_{52}$ Jemalong cultivar gives an average of $17 \mathrm{~cm}$. Number of stems by square meter varies between $136 \mathrm{chez} \mathrm{C}_{204}$ and $420 \mathrm{chez}$ $\mathrm{I}_{52}$. Number of plants by square meter varies between 112 to 44 ; cultivar Jemalong gives a number of 48 (Tab. 2).

Generally, it is well known that leaves-stems ratio is a good indicator of the forage quality and offers a potential for cultivars selection, this last one varies at the beginning of flowering in 2015 between 5 in population of $S_{5}$ and 1.03 in population of $\operatorname{Tr}_{334}$. In M.truncatula, it varies of 1.03 in $\operatorname{Tr}_{334}$ and 2,81 in $\operatorname{Tr}_{238}$ while in Jemalong cultivar species, it gives a ratio close of the latter $(2,8)$ (Tab.2) while in 2013, it varies between 0,5 in Poly 205 and 2,91 in $\mathrm{Tr}_{407}$. Porquiddu (2001) records lower values in M.polymorpha $c v$. Cercle Valley that $M$ truncatula. cv. Chypre et M. Tornata cv. Dornafield with respectively $0.97,0.80$ and 0,76 . A decrease of this ratio is observed during pods and grains formation probably linked to their high demand for products of photosynthesis with presence of species interaction $x$ age Derkaoui et al., 1990). The percentage of viable plants at early flowering stage varies in 2013 between $37,08 \%$ in $\operatorname{Tr}_{334}$ and $19,16 \%$ in $\operatorname{Tr}_{55}$. Average between species varies between $24.06 \%$ in M.polymorpha and between $29.32 \%$ in M.intertexta. In 2015 this same parameter (Tab.2) varies between $0 \%$ in M.polymorpha and most of M.truncatula reaches $35 \%$ in M.intertexta, Jemalong cultivar offers a viability of $15 \%$. We can say that both species (M.truncatula, M.intertexta) are more resistant to abiotic stress than other both species (M.plymorpha, M.truncatula) probably due to the grains size.

The Fisher's test offers homogeneous groups for biometrical parameters of forage production (Tab.2). By contrast, for production of pods, no group is formed. The growing cycle parameter of the plan offers seven groups which overlap, except for populations $\operatorname{Tr}_{27}$ and $I_{52}$ where there is not overlapping. As for matter, green, dry and width of ramifications, population $\mathrm{I}_{52}$ is individualized from other groups. The LS ratio in dry, forms with population $\mathrm{S}_{5}$ the homogeneous group $a$ and population $\mathrm{I}_{52}$ and $\operatorname{Tr}_{334}$ form another group $\mathrm{d}$ which did not overlap with other.

Table.2: Average of biometrical parameters studied for production of dry matter in MedicKs populations studied.

\begin{tabular}{|c|c|c|c|c|c|c|c|c|}
\hline Populations & $\begin{array}{l}\text { Cycle in } \\
\text { days }\end{array}$ & $\begin{array}{c}\text { Number } \\
\text { of plants } \\
\text { by } \mathbf{m}^{2}\end{array}$ & $\begin{array}{c}\text { Number } \\
\text { stems by } \\
\mathbf{m}^{\mathbf{2}}\end{array}$ & $\begin{array}{l}\text { Width } \\
\text { in cm }\end{array}$ & $\begin{array}{l}\text { MV } \\
\mathrm{g} / \mathrm{m}^{2}\end{array}$ & $\begin{array}{l}\mathrm{MS} \\
\mathbf{g} / \mathbf{m}^{2}\end{array}$ & F/T Sec & $\begin{array}{r}\text { Perc of } \\
\text { viability }\end{array}$ \\
\hline $\mathbf{S}_{5}$ & $110 \mathrm{fg}$ & $70,67 \mathrm{abc}$ & $209,33 \mathrm{abc}$ & $18 \mathrm{ef}$ & $160 \mathrm{efg}$ & $\begin{array}{c}53,79 \\
\text { def }\end{array}$ & $4,5 \mathrm{a}$ & 22,08 \\
\hline$S_{15}$ & $110 \mathrm{~g}$ & $66 \mathrm{bc}$ & $154 \mathrm{c}$ & $13,5 \mathrm{ef}$ & $91,2 \mathrm{efg}$ & $\begin{array}{c}12,56 \\
\text { def }\end{array}$ & $2,43 \mathrm{bcd}$ & 20,625 \\
\hline $\mathrm{C}_{2}$ & $114 \mathrm{efg}$ & $100 \mathrm{bc}$ & $244 \mathrm{bc}$ & $19,5 \mathrm{ef}$ & 129,613 & $\begin{array}{c}27,253 \\
\text { def }\end{array}$ & $4,02 \mathrm{bcd}$ & 31,25 \\
\hline $\mathbf{S}_{7}$ & $115 \mathrm{efg}$ & $64 \mathrm{bc}$ & $260 a b c$ & $22,25 \mathrm{ef}$ & $\begin{array}{c}205,46 \\
\text { efg }\end{array}$ & $\begin{array}{c}37,06 \\
\text { def }\end{array}$ & $3,16 \mathrm{bcd}$ & 20 \\
\hline $\mathbf{S}_{3}$ & 116def & $44 \mathrm{bc}$ & $156 \mathrm{bc}$ & $20 \mathrm{ef}$ & 80 efg & 320def & $5 b$ & 13,75 \\
\hline $\mathrm{C}_{11}$ & 116def & 64abc & $276 \mathrm{bc}$ & $18 \mathrm{ef}$ & 244,4 efg & $\begin{array}{c}47,68 \\
\text { def }\end{array}$ & $3,21 b c$ & 20 \\
\hline $\mathrm{C}_{204}$ & 116def & $56 a b c$ & $136 \mathrm{bc}$ & $23 \mathrm{ef}$ & $158,04 \mathrm{efg}$ & 33def & $3,64 \mathrm{bcd}$ & 17,5 \\
\hline $\mathrm{C}_{58}$ & $120,33 \mathrm{~cd}$ & $54,67 \mathrm{bc}$ & $189,33 \mathrm{bc}$ & 20,33def & $\begin{array}{c}252,87 \\
\text { Defg }\end{array}$ & $\begin{array}{c}91,567 \\
\text { cde }\end{array}$ & $2,33 \mathrm{bcd}$ & 18,125 \\
\hline CV & $118 \mathrm{de}$ & $48 c$ & $116 \mathrm{c}$ & $17 \mathrm{ef}$ & 78,96 & $\begin{array}{c}12,8 \\
\text { def }\end{array}$ & $2,8 \mathrm{~cd}$ & 15 \\
\hline $\operatorname{Tr}_{238}$ & $117 \mathrm{de}$ & $76 \mathrm{ac}$ & $312 a b c$ & $18,5 \mathrm{ef}$ & $\begin{array}{c}256,54 \\
\text { efg }\end{array}$ & $\begin{array}{c}\text { 74,06 } \\
\text { def }\end{array}$ & $2,81 \mathrm{bcd}$ & 23,75 \\
\hline $\operatorname{Tr}_{334}$ & $128,33 \mathrm{ab}$ & $70,67 \mathrm{bc}$ & $209,33 \mathrm{bc}$ & $13 \mathrm{f}$ & $80 \mathrm{fg}$ & $51,72 \mathrm{f}$ & $1,03 \mathrm{~d}$ & 18,125 \\
\hline $\mathbf{T r}_{27}$ & $130 \mathrm{a}$ & $28 \mathrm{bc}$ & $172 \mathrm{c}$ & $19 \mathrm{ef}$ & $140 \mathrm{efg}$ & 36bef & $1,28 \mathrm{~cd}$ & 18,500 \\
\hline $\mathbf{I}_{253}$ & $124 b c$ & 112a- & $420 \mathrm{a}$ & $38,33 a b c$ & 1072abc & $196 \mathrm{ab}$ & $2,07 \mathrm{bcd}$ & 35 \\
\hline I 756 & $124,67 b c$ & 94,67ab- & $353,33 \mathrm{ab}$ & 36abcd & $\begin{array}{c}749,33 \\
\text { abcd }\end{array}$ & $\begin{array}{c}141,33 \\
a b c\end{array}$ & $1,94 \mathrm{bcd}$ & 23,88 \\
\hline $\mathbf{I}_{107}$ & 124,33 & $60 \mathrm{bc}$ & $314,67 \mathrm{abc}$ & 40,67 & 942,67 & 174,67 & $1,66 \mathrm{~cd}$ & 25,79 \\
\hline
\end{tabular}




\begin{tabular}{|c|c|c|c|c|c|c|c|c|}
\hline & $\mathrm{bc}$ & & $\mathrm{ab}$ & $\mathrm{ab}$ & $\mathrm{Ab}$ & & \\
\hline $\mathbf{I}_{\mathbf{1 1}}$ & $126 \mathrm{ab}$ & $86,67 \mathrm{ab}-$ & $332 \mathrm{ab}$ & $27 \mathrm{cde}$ & $41,5 \mathrm{cdef}$ & 166 & $2,53 \mathrm{bcd}$ & 27,083 \\
\hline $\mathbf{I}_{\mathbf{5 8}}$ & $126,67 \mathrm{ab}$ & $61,33 \mathrm{bc}$ & $248 \mathrm{abc}$ & $\begin{array}{c}29,67 \mathrm{bcd} \\
\mathrm{e}\end{array}$ & $\begin{array}{c}530,67 \\
\mathrm{bcde}\end{array}$ & 117,33 & $1,55 \mathrm{~cd}$ & 19,167 \\
\hline $\mathbf{I}_{\mathbf{3 1}}$ & $\begin{array}{c}126,67 \\
\mathrm{ab}\end{array}$ & $74 \mathrm{abc}$ & $290 \mathrm{bc}$ & $\begin{array}{c}28,33 \\
\mathrm{abc}\end{array}$ & $\begin{array}{c}113,33 \\
\mathrm{abc}\end{array}$ & $\begin{array}{c}453,33 \\
\mathrm{ab}\end{array}$ & $1,32 \mathrm{~cd}$ & 25 \\
\hline $\mathbf{I}_{\mathbf{5 2}}$ & $130 \mathrm{a}$ & $86,67 \mathrm{ab}-$ & $420 \mathrm{a}$ & $44 \mathrm{a}$ & $1277,06 \mathrm{a}$ & $260 \mathrm{a}$ & $1,11 \mathrm{~d}$ & 27,08 \\
\hline
\end{tabular}

Our yields pods in littoral region in 2013 vary between $79.88 \mathrm{~g} / \mathrm{m}^{2}$ in poly 27 and $3637.33 \mathrm{~g} / \mathrm{m}^{2}$ in $\mathrm{I}_{107}$ (Alane et $a l$., 2014). Values of the second essay (2015) are different, they vary between $40,89 \mathrm{~g} / \mathrm{m}^{2}$ in Poly 236 and $464,36 \mathrm{~g} / \mathrm{m}^{2}$ in $\mathrm{I}_{11}$. The cultivar Jemalong offers a yield of $172.4 \mathrm{~g} / \mathrm{m} 2$, if we compare it to local species of M.truncatula, population $\operatorname{Tr}_{238}$, it gives a higher yield of $247,51 \mathrm{~g} / \mathrm{m}^{2}$ (Tableau 3) while yield of pods obtained by l'ITGC in 1977 in sublittoral zone was of $10 \mathrm{~g} / \mathrm{m}^{2}$. The results comparison of both experiment years show a different yield: for instance year 2013, yield of both quoted populations (Aus ${ }_{106} 944 \mathrm{~g} / \mathrm{m}^{2}, \mathrm{I}_{11} 2428,444 \mathrm{~g} / \mathrm{m}^{2}$ ) is superior to that of year 2015 (AUS ${ }_{106} 13 \mathrm{~g} / \mathrm{m}^{2}, \mathrm{I}_{11} 464,36 \mathrm{~g} / \mathrm{m}^{2}$ ). Furthermore, some populations as Poly $_{27}$ have not germinated. This result may be explained by difference of weather conditions between both years of experiments. Soil of the first essay is well fertilized having experienced several essays on medicKs, thus well provided in rhizobium, unlike to soil of the second essay which was a fallow during several years. In addition, climatic data of the first essay record an abundant rainfall compared to that of the second test.

Yields in seeds corresponding to performances in pods produced $\left(\mathrm{g} / \mathrm{m}^{2}\right)$, also show for the same reasons, a low production in 2015 compared to 2013. Since they vary in 2013 between 21,533 g/m² in Poly 27 and 900,375g/m² in $\mathrm{I}_{107}$ while introduced population Aus ${ }_{106}$ gives a yield of $359,077 \mathrm{~g} / \mathrm{m}^{2}$ (Alane et al., 2014). In 2015 the essay gives in seeds yield which varies between $425,67 \mathrm{~g} / \mathrm{m}^{2}$ in $\mathrm{S}_{7}$ and of $5,71 \mathrm{~g} / \mathrm{m}^{2}$ in $\mathrm{I}_{52}$ (Table.3). According to Laouar et $\boldsymbol{a l}$ (2000) $M$.ciliaris is earlier and products more plant/pods but with a low number of pod/grains, contrary to $M$ intertexta.
However, according to results of our essays, we confirm precociousness of M.ciliaris's populations (Fig.1), but for production of seed, yield of M.intertexta depends of annual weather conditions since in 2013, average yield of M.intertexa exceeds that of M.ciliaris (S :354,602g/m², I $: 821,997 \mathrm{~g} / \mathrm{m}^{2}$ ) while in 2015 the contrary occurred (S: $\left.106,20575 \mathrm{~g} / \mathrm{m}^{2}, \mathrm{I}: 55,215 \mathrm{~g} / \mathrm{m}^{2}\right)$.Jemalong cultivar gives a yield of $40,936 \mathrm{~g} / \mathrm{m}^{2}$. This also has been observed in clover by Clark (2014) who noticed that cycle of clover varies from 100 to 126 days after seeding depending of the place, and of timing of sowing, and so of cultivars used. The introduced population in our essay Aus 106 gives the lowest yield $4,51 \mathrm{~g} / \mathrm{m}^{2}$ (Table 3 ).

For information purpose, populations with early flowering have trend to belong to drier habitats and the hottest, and numerous authors found similar results in several other annual pulses (Graziano et $\boldsymbol{a l}, \mathbf{2 0 1 0}$ ).

Furthermore, population's origin influences directly on weight of 1000 grains where itself influences on yield. In effect, populations which come from areas with more annual rainfalls had more small pods and grains at upper sizes than of dry environments (Graziano et al., 2010). These results are confirmed by Del Pozo et al (2002) who affirm that sizes of grains and pods have an adaptive value. Nevertheless, the grains performance may be reduced through over-grazing, freeze, and drought. (Muir et $\boldsymbol{a l}$., 2005). Since $70 \%$ of feedings have been insured by pods of MedicKs, proportion decreased rapidly to zero when green material becomes available after rain (Porqueddu., 2001). Much of leguminous fodder species are depending to permanent grassland (Duc et al., 2010). Weight of grains constitutes a compensation mechanism to support grain yield under impact of the drought (Yousfi et al., 2012).

Table.3: Average of biometrical parameters studied for production of pods and seed in medics' populations studied.

\begin{tabular}{|l|l|l|l|l|}
\hline Populations & Weight of 50 pods & $\begin{array}{l}\text { Weight of seed of } \\
\mathbf{5 0} \text { pods }\end{array}$ & $\begin{array}{l}\text { Yield in pods } \\
\mathbf{g} / \mathbf{m}^{\mathbf{2}}\end{array}$ & $\begin{array}{l}\text { Yield of seed } \\
\mathbf{g} / \mathbf{m}^{\mathbf{2}}\end{array}$ \\
\hline $\mathbf{S}_{\mathbf{5}}$ & 12,13 & 2,98 & 254,8 & 63,72 \\
\hline $\mathbf{S}_{\mathbf{1}}$ & 9,64 & 2,89 & 142,54 & 42,27 \\
\hline $\mathbf{C}_{\mathbf{2}}$ & 13,64 & 3,38 & 345,8 & 87,01 \\
\hline $\mathbf{S}_{\mathbf{7}}$ & 15,62 & 3,84 & 425,67 & 425,67 \\
\hline $\mathbf{S}_{\mathbf{3}}$ & 13,28 & 3,58 & 245,9 & 66,29 \\
\hline $\mathbf{C}_{\mathbf{1 1}}$ & 12,97 & 3,42 & 241,2 & 60,72 \\
\hline
\end{tabular}




\begin{tabular}{|c|c|c|c|c|}
\hline $\mathrm{C}_{204}$ & 17,08 & 4,85 & 163,47 & 46,25 \\
\hline $\mathrm{C}_{58}$ & 9,71 & 2,74 & 392,93 & 57,75 \\
\hline CV Tr & 1,99 & 0,47 & 172,4 & 40,94 \\
\hline $\mathbf{T r}_{407}$ & 3,32 & 0,74 & 66,567 & 16,18 \\
\hline Tr201 & 6,43 & 1,56 & 170,8 & 41,42 \\
\hline $\operatorname{Tr}_{238}$ & 5,87 & 1,524 & 247,51 & 65,25 \\
\hline Tr334 & 4,99 & 1,40 & 113,3 & 31,96 \\
\hline I755 & 13,46 & 3,19 & 86,133 & 20,73 \\
\hline $\mathbf{I}_{756}$ & 17,76 & 4,79 & 320,8 & 86,17 \\
\hline I107 & 18,27 & 4,24 & 283,53 & 71,58 \\
\hline$I_{11}$ & 17,82 & 3,70 & 464,36 & 97,07 \\
\hline $\mathbf{I}_{31}$ & 16,53 & 4,023 & 197,3 & 50,03 \\
\hline$I_{52}$ & 21,53 & 36,80 & 175,45 & 5,71 \\
\hline Poly205 & 4,76 & 1,16 & 75,6 & 36,80 \\
\hline Poly 236 & 1,18 & 0,29 & 40,89 & 9,97 \\
\hline AUS $_{106}$ & 3,353 & 1,16 & 13 & 4,51 \\
\hline
\end{tabular}

Variance analysis of dry matter production parameters, shows great significance $(\mathbf{p}<\mathbf{0}, \mathbf{0 0 0 1})$ (Table 4). The correlation matrix of these parameters for a ddI of 48 is reported in table (5). Parameters' variance analysis of pods yield and populations 'seed studied also show a highly significant difference $(\mathrm{p}<\mathbf{0 , 0 0 0 1})$ (Table 6). Correlation matrix of these parameters for ddI of 68 is reported in table (7).

Table.4: Univariate analysis of dry matter production parameters

\begin{tabular}{|c|c|c|c|c|c|c|}
\hline Parameters & Variance & DDL & Chi2 & P & $95 \%$ inf & $95 \%$ sup \\
\hline Number of plant & 47,930 & 56 & 2684,097 & $<0,0001$ & 36,043 & 67,437 \\
\hline Number of stems & 896,770 & 54 & 48425,602 & $<0,0001$ & 671,150 & 1270,472 \\
\hline Width $(\mathrm{cm})$ & 123,931 & 55 & 6816,214 & $<0,0001$ & 92,976 & 174,963 \\
\hline $\mathrm{L} / \mathrm{S}(\mathrm{green})$ & 49,077 & 56 & 2748,304 & $<0,0001$ & 36,906 & 69,051 \\
\hline $\mathrm{L} / \mathrm{S}(\mathrm{dry})$ & 13,896 & 56 & 778,173 & $<0,0001$ & 10,450 & 19,551 \\
\hline $\mathrm{GMg} / \mathrm{m}^{2}$ & 177410,971 & 56 & 9935014,349 & $<0,0001$ & 133412,622 & 249615,463 \\
\hline $\mathrm{DMg} / \mathrm{m}^{2}$ & 6283,627 & 55 & 345599,462 & $<0,0001$ & 4714,124 & 8871,072 \\
\hline
\end{tabular}

Table.5: Correlation matix of dry matter production parameters

\begin{tabular}{|l|l|l|l|l|l|l|}
\hline & $\begin{array}{l}\text { Number of } \\
\text { plant }\end{array}$ & $\begin{array}{l}\text { Number of } \\
\text { stems }\end{array}$ & $\begin{array}{l}\text { Width of } \\
\text { ramifications }\end{array}$ & $\begin{array}{l}\text { Rapport } \\
\mathbf{L} / \mathbf{S}(\mathbf{d r y})\end{array}$ & $\begin{array}{l}\mathbf{G M} \\
\mathbf{g} / \mathbf{m}^{2}\end{array}$ & $\begin{array}{l}\mathbf{D M} \\
\mathbf{g} / \mathbf{m}^{2}\end{array}$ \\
\hline Number of plant & 1 & & & & & \\
\hline Number of stems & $0,685^{* * *}$ & 1 & & & & \\
\hline $\begin{array}{l}\text { Width of } \\
\text { ramifications }\end{array}$ & 0,188 & $0,481^{* * *}$ & 1 & & & \\
\hline Rapport L/S(vert) & 0,256 & $-0,139$ & $-0,314^{*}$ & & & \\
\hline Rapport L/S(sec) & 0,127 & $-0,167$ & $-0,291^{*}$ & 1 & & \\
\hline $\mathbf{G M ~} \mathbf{g} / \mathbf{m}^{\mathbf{2}}$ & $0,447^{* * *}$ & $0,772^{* * *}$ & $0,862^{* * *}$ & $-0,218$ & 1 & \\
\hline $\mathbf{D M ~} \mathbf{g} / \mathbf{m}^{2}$ & $0,401^{* * *}$ & $0,687^{* * *}$ & $0,788^{* * *}$ & $-0,177$ & $0,934^{* * *}$ & 1 \\
\hline
\end{tabular}

Table.6: Univariate analysis of pods yield parameters

\begin{tabular}{|c|c|c|c|c|c|c|}
\hline Parameters & Variance & DDL & Chi2 & p & 95\% inf & 95\% sup \\
\hline Weight of 50 pods & 680,096 & 69 & 46926,641 & $<0,0001$ & 524,958 & 922,214 \\
\hline Seed of 50 pods & 7,303 & 69 & 503,884 & $<0,0001$ & 5,637 & 9,904 \\
\hline $\begin{array}{c}\text { Weight of collected } \\
\text { Pods }\end{array}$ & 10029,572 & 69 & 692040,458 & $<0,0001$ & 7741,706 & 13601,626 \\
\hline
\end{tabular}




\begin{tabular}{|c|c|c|c|c|c|c|}
\hline Seed of collected pods & 3778,920 & 69 & 260745,462 & $<0,0001$ & 2916,903 & 5124,790 \\
\hline Yield of pods in $\mathbf{g} / \mathbf{m}^{\mathbf{2}}$ & 27789,048 & 69 & 191744,294 & $<0,0001$ & 21450,032 & 37686,179 \\
\hline Yield of seed in $\mathbf{g} / \mathbf{m}^{\mathbf{2}}$ & 1754,650 & 69 & 121070,833 & $<0,0001$ & 1354,393 & 2379,572 \\
\hline
\end{tabular}

Table.7: Correlation matrix of dry matter production parameters

\begin{tabular}{|l|l|l|l|l|l|l|}
\hline & $\begin{array}{l}\text { Weight of 50 } \\
\text { pods }\end{array}$ & $\begin{array}{l}\text { Seed of 50 } \\
\text { pods }\end{array}$ & $\begin{array}{l}\text { Weight of } \\
\text { collected } \\
\text { pods }\end{array}$ & $\begin{array}{l}\text { Seed of } \\
\text { collected } \\
\text { pods }\end{array}$ & $\begin{array}{l}\text { Yield of pods } \\
\mathbf{g} / \mathbf{m}^{2}\end{array}$ & $\begin{array}{l}\text { Yield } \\
\text { of seed } \\
\mathbf{g} / \mathbf{m}^{2}\end{array}$ \\
\hline Weight of 50 pods & 1 & & & & & \\
\hline Seed of 50 pods & $0,925^{* * *}$ & 1 & & & & \\
\hline Weight of collected pods & $-0,091$ & 0,085 & 1 & & & \\
\hline Seed of collected pods & 0,043 & 0,187 & $0,584^{* * *}$ & 1 & & \\
\hline $\begin{array}{l}\text { Yield of pods } \\
\text { g/m }\end{array}$ & 0,203 & $0,346^{* *}$ & $0,749^{* * *}$ & $0,535^{* * * *}$ & 1 & \\
\hline $\begin{array}{l}\text { Yield of seed } \\
\text { g/m }\end{array}$ & 0,203 & $0,368^{* * *}$ & $0,690^{* * *}$ & $0,534^{* * * *}$ & $0,973^{* * *}$ & 1 \\
\hline
\end{tabular}

Number of homogeneous groups given by Fisher's test for green matter production parameters at early flowering is shown in table (2). No homogeneous group is given for pods production parameters.
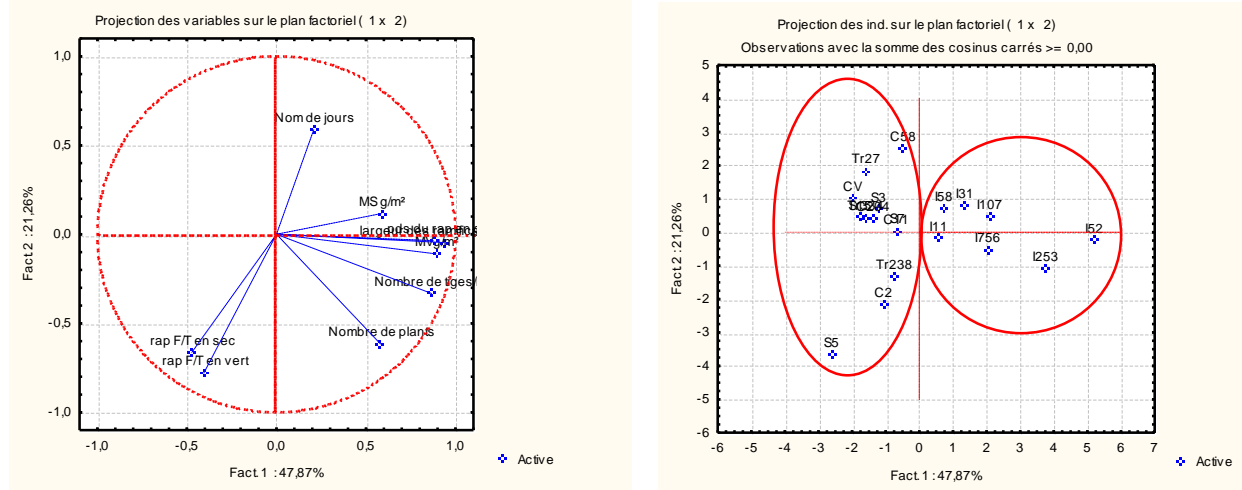

Fig.2: Principal Components Analysis (PCA) of dry production parameters
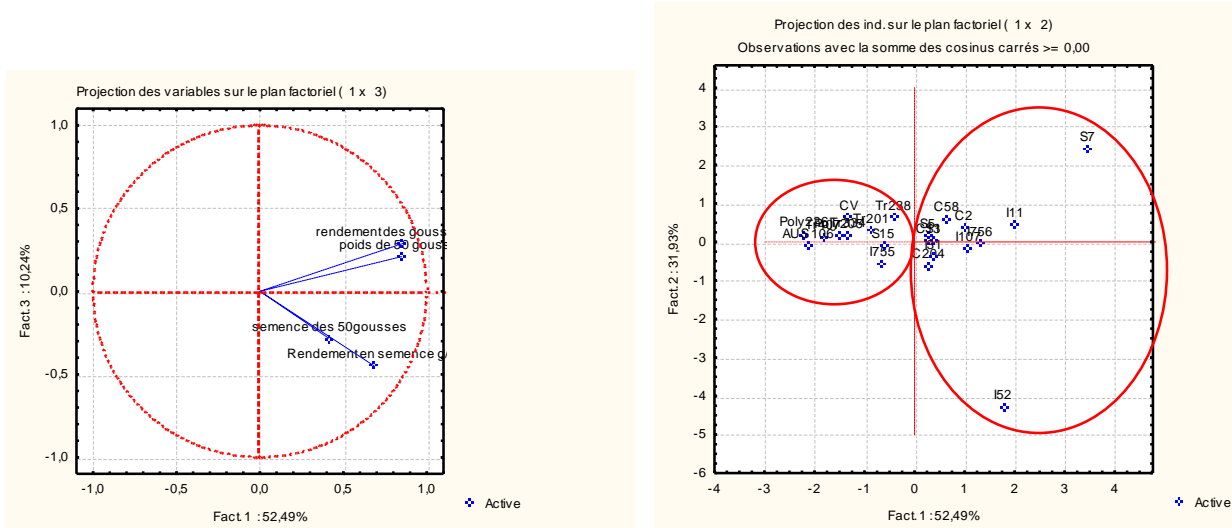

Fig.3: Principal Components Analysis (PCA) of pods production parameters.

Principal Components Analysis (PCA) led us to the study of Kaiser Criterion, this one offers us for dry matter production parameters, three designs $(1,2),(1,3), 2,3)$ and in elbow criterion, we observe an important fall from the first axis (of $47,87 \%$ to $8,96 \%$ of inertia). We retained the first factorial design (1 and 2) (Figure 2) which gives information of $69.13 \%(47,87+21,26=69,13 \%)$ parameters that are close to circle are $\mathrm{GM}\left(\mathrm{g} / \mathrm{m}^{2}\right)$, width of ramifications, weight which served to the ratio determination, number of stems, number of plants and 
ratio in green and dry, thus they are effectively well correlated with the two factors used for this design (F1 and F2), by contrast, dry matter $\left(\mathrm{DM} / \mathrm{m}^{2}\right)$ and cycle of the plant in day number are less near to the circle.

The first information axis, whereby is preserved by projection of maximum initial dispersion of points of the cloud. All variables occupy a fairly narrow zone inside of the correlations circle. Maximum angle between two variables is below $90^{\circ}$. This suggests that all variables are positively correlated between them. So, two large populations groups are formed, the first one based on parameters : GM, DM, width of ramifications, weight served to ratio determination, number of stems containing M.intertexta $\quad\left(\mathrm{I}_{31}, \mathrm{I}_{11}, \mathrm{I}_{107}, \mathrm{I}_{58}, \mathrm{I}_{756}, \mathrm{I}_{253}, \mathrm{I}_{52}\right)$ the second group containing M.ciliaris and M.truncatula $\left(S_{3}, S_{5}, \mathrm{cv}, C_{204}\right.$, $\left.C_{11}, T_{27}, \quad \operatorname{Tr}_{334,} \operatorname{Tr}_{238}, C_{2}, C_{58}\right)$ are determined by parameters ratio leaves/stems in green and in

For pods production, the Kaiser Criterion, led us to retain two axes and in elbow criterion, we observe an important fall from the first axis (de $52,49 \%$ to $10,24 \%$ of inertia). In the first design, all parameters are close of the circle, thus, they are effectively well correlated with both factors constituting this design (F1 and F2). The first factorial axis gives $(52,49 \%+31,93 \%=84,42 \%)$, axis that is preserved, by projection of maximum initial dispersion of cloud points. All variables occupy a rather limited area inside of the correlations circle Maximum angle between two variables is below $90^{\circ}$. This suggests that all variables are positively correlated between. And so, two populations groups are formed. The first group determined by all parameters studied includes only both species : M.ciliaris and M.intertexta $\left(\mathrm{S}_{7}, \mathrm{~S}_{5}, \mathrm{I}_{52}\right.$, $\left.\mathrm{C}_{58}, \mathrm{~S}_{3}, \mathrm{I}_{756}, \mathrm{C}_{11}, \mathrm{C}_{2}, \mathrm{C}_{204}, \mathrm{I}_{107}, \mathrm{I}_{11}\right)$ while the second group is a mixture of species examined M.ciliaris , M.intertexta, M.truncatula ,M.polymorpha, M.granadensis ( poly $_{236}$, Aus 106, $\operatorname{Tr}_{106}, \operatorname{Tr}_{407}, \mathrm{CV}$,poly205, $\operatorname{Tr}_{334}, \operatorname{Tr}_{201}, \operatorname{Tr}_{238}, \mathrm{~S}_{15}, \mathrm{I}_{755}$.

\section{CONCLUSION}

Evaluation of genetic material of medics based on agronomic aspects should take into account of appropriate variability for some characteristics linked to fodder and to production of pods. The results of comparison of both years of experimentation show a different yield: that of 2013 is higher than of 2015. Some populations had not germinated in the last essay. Weather conditions strongly influence on quantity of dry matter produced and also on yield of pods and seed. Both species (M.ciliaris, M.intertexta) are more resistant to abiotic stress than other both species M.plymorpha, M.truncatula) probably due to the grain's size. M.ciliaris are earlier than other local species but for seed production, yield of M.intertexta depends of annual weather conditions since in 2013 average yield of M.intertexta exceeds that of M.ciliaris
$\left(\mathrm{S}: 354,602 \mathrm{~g} / \mathrm{m}^{2}, \quad \mathrm{I}: 821,997 \mathrm{~g} / \mathrm{m}^{2}\right)$ while in 2015 the opposite happened (S: 106,20575g/m², I : $\left.55,215 \mathrm{~g} / \mathrm{m}^{2}\right)$. Moreover, this is the last ones which lose their leaves and their greenery until half of June and have a broader land use than other species.

Jemalong cultivar is earlier than all populations studied, but it records a low yield in dry matter and in pods. Variance analysis of dry matter production parameters shows a very high significance $(p<0,0001)$. Principal components analysis (PCA) of dry matter production parameters forms two large populations groups: the first based on parameters: green matter (GM), dry matter (DM), width of ramifications, weight served to the ratio determination, number of stems containing only in M.intertexta $\left(\mathrm{I}_{31}, \mathrm{I}_{11}, \mathrm{I}_{107}, \mathrm{I}_{58}, \mathrm{I}_{756}, \mathrm{I}_{253}, \mathrm{I}_{52}\right)$, the second group containing M.ciliaris and M.truncatula $\left(\mathrm{S}_{3}, \mathrm{~S}_{5}, \mathrm{cv}, \mathrm{C}_{204}\right.$, $\mathrm{C}_{11}, \operatorname{Tr}_{27}, \operatorname{Tr}_{334}, \operatorname{Tr}_{238}, \mathrm{C}_{2}, \mathrm{C}_{58}$ ) are determined by ratio parameters leaves/stems in green and in dry. Therefore, parameters of pods production form two other populations groups. The first group determined by all parameters examined comprises only both species M.ciliaris and M.intertexta $\quad\left(\mathrm{S}_{7}, \mathrm{~S}_{5}, \mathrm{I}_{52}, \mathrm{C}_{58}, \mathrm{~S}_{3}, \mathrm{I}_{756}, \mathrm{C}_{11}, \mathrm{C}_{2}, \mathrm{C}_{204}, \mathrm{I}_{107}, \mathrm{I}_{11}\right)$ while the second group is a mixture of species examined M.ciliaris , M.intertexta, M.truncatula ,M.polymorpha, M.granadensis ( poly ${ }_{236}, \mathrm{Aus}_{106}, \mathrm{Tr}_{106}, \mathrm{Tr}_{407}, \mathrm{CV}$,poly ${ }_{205}$, $\operatorname{Tr}_{334}, \operatorname{Tr}_{201}, \operatorname{Tr}_{238}, \mathrm{~S}_{15}, \mathrm{I}_{755)}$.

Results of medics seed production depend on weather conditions in littoral area, of altitude lower than $600 / 700 \mathrm{~m}$. In steppe regions, it is necessary to make trials in situ with these known populations. Mixture of population seeding with small and large grains: will give a better ecological balance and in the same time a high nutritional value. Finally, to control seed population of annual alfalfa (Medics) some number of significant barriers must be overcome: seed bed, maintenance, operation, cultivation through grazing, are determinant on results of pods harvesting. This is particularly delicate and requires an appropriate material.

\section{REFERENCES}

[1] Abdeguerfi.A. (2002). ressources génétiques d'interêt pastoral et/ou fourrager: Distribution et variabilité chez le légumineuses spontanées (Medicago, Trifolum, Scorpiurus, Hedysarum et Onobrychis) en Algérie :thése doctorat INA .433p.

[2] Alane.F., Chabaca.R., Abdelgherfi-Laouar and M,Abdelgherfi A. (2015). Seed Potentialities Of Medics In Subhumid ZoneWith A View To Use Them In Steppe Zone.International Journal of Agriculture and Crop Sciences. Available online at www.ijagcs.com IJACS/2015/8-2/181-186 ISSN 2227-670X @2015 IJACS Journal 
[3] Babita Thapa .(2008).Understanding cold acclimation in Medicago truncatula". Graduate Theses and Dissertations. Paper 11940. http://lib.dr.iastate.edu/cgi/viewcontent.cgi?article $=2$ 970\&context=etd

[4] Bouaboub- Moussab .K.(2001). Comportement des variétés et des populations de la luzerne pérenne Medicago sativa $\mathrm{L}$. dans la région de d'Adrar. thèse de magister INA El Harrach. 152p.

[5] Clark, Shawnna. (2014). Plant guide for bur clover (Medicago polymorpha L.) USDA-Natural Resources Conservation Service, Big Flats Plant Materials Center, corning New York.

[6] Del Pozo

.A., Ovalle.C., Aronson.J., Avendaño.J. (2002) . Ecotypic differentiation in Medicago POLYMORPHA L. along an environmental gradient in central Chile. II. Winter growth as related to phenology and temperature regime .Volume 160, Issue 1, pp 53-59

[7] Derkaoui.M ., Caddel .J.L. and Stroup, W.W.(1990). Biomass partitioning and root development in annual Medicago spp. Agr. Med., 120: 407-416.

[8] Duc. G., Mignolet. C., Carrouée .B., Huyghe.C. (2010) . Importance économique passée et présente des légumineuses : Rôle historique dans les assolements et facteurs d'évolution. Innovations Agronomiques 11 (2010), 1-24

[9] FAO. (2015). 2016 Année internationale des légumineuses: des graines pour nourrir l'avenir. Brochure

[10] Graziano. D., G. DiGiorgio, P. Ruisi ., G. Amato and D. Gianbalvo (2010). Variation in phenomorphological and agronomic traits among burr medic (Medicago polymorpha L.) populations collected in Sicily, Italy. Crop and Pasture Science. 61:59-69.

[11]ITGC (Institut de développement des grandes cultures). (1976). Résultats et perspectives d'extension de la luzerne annuelle(Medicago).Revue céréaliculture $\mathrm{n}^{\circ} 1.28-31$

[12] James .P. Muir, William.R., Ocumpaugh and Twain J. Butler.(2005). Trade-Offs in Forage and Seed Parameters Annual Medicago and Trifolium Species in NorthCentral Texas as Affected by Harvest Intensity. American Society of Agronomy. American Society of Agronomy https://www.agronomy.org/

[13] Laouar . M..,Abdelguerfi .A. and Kouchi K. (2000) . Etude du complexe d'espèce Medicago clliarisM.inlertexta variabilité morphologie et phénologique. Annales de f1nstitut National
Agronomique - EI-HamJch - Vol .21, N" 1 et 2, 200051

[14] Nasreddine.Yousfi.,Ines.

Slama.,Chedly.,Abdelly.( 2012) . Phenology, leaf gas exchange, growth, and seed yield in contrasting Medicago truncatula and Medicago laciniata populations during prolonged water deficit and recovery . Botanique, 90(2): 79-91, 10.1139/b11-093

[15] Panciera. Sparrow., Panciera. MT., Sparrow .SD. (1995) . Effects of nitrogen fertilizer on dry matter and nitrogen yields of herbaceous legumes in interior. Alaska. Can J Plant Sci 1995

[16] Piano . E. and Talamucci,. P. (1996). Annual selfregenerating legumes in Mediterranean areas. Grassland Science in Europe, I, 895-909. ERSA.

[17] Porqueddu .C. (2001).Screening germplasm and varieties for forage quality: Cons traints and potentials in annual medics in Delgado I. ( ed.), Lloveras J. ( ed.) Quality in lucerne and medics for animal production .Zaragoza : CIHEAM Options Méditerranéennes : Série A. Séminaires Méditerranéens; n. 45 pages 89 - 98

[18] SAREP. ( 2013). SAREP Cover Crops. 2013. Burr Médic.

http://www.sarep.ucdavis.edu/database/covercrops (accessed 3 Feb 2013)

[19] Seklani.H ., Hassen .H (1990). Contribution à l'étude des espèces spontanées du genre Medicago en Tunisie. Ann. INRAT 63: 3-15 . In Seklani H., Zoghlami A., Mezni

[20] M .., Hassen .(1996.) Synthèse des travaux de recherche réalisés sur les Medicago à l'Institut National de la Recherche Agronomique de Tunisie. in Genier G. (ed.),Prosperi J.M. (ed.). The Genus Medicago in the Mediterranean region: Current situation and prospects in research Zaragoza: CIHEAM Cahiers Options Méditerranéennes; n. 18 1 . pages $31-37$ 